\title{
Formulation development of oral controlled release tablets of hydralazine: Optimization of drug release and bioadhesive characteristics
}

BHUPINDER SINGH*

SONIA PAHUJA

RISHI KAPIL

NAVEEN AHUJA

University Institute of Pharmaceutical Sciences (UGC Centre for Advanced Studies), Panjab University

Chandigarh-160014, India
Accepted January 15, 2009

\begin{abstract}
The current study involves development of oral bioadhesive hydrophilic matrices of hydralazine hydrochloride, and optimization of their in vitro drug release profile and ex vivo bioadhesion against porcine gastric mucosa. A $3^{2}$ central composite design was employed to systematically optimize the drug delivery formulations containing two polymers, viz., carbomer and hydroxypropyl methyl cellulose. Response surface plots were drawn and optimum formulations were selected by brute force searches. Validation of the formulation optimization study indicated a very high degree of prognostic ability. The study successfully undertook the development of an optimized once-a-day formulation of hydralazine with excellent bioadhesive and controlled release characteristics.
\end{abstract}

Keywords: hydralazine, experimental design, bioadhesive, response surface methodology, gastrointestinal therapeutic system, hydrophilic matrices

Oral controlled release (CR) systems constitute the most »sought after « route of drug administration since they obviate the need of frequent dosage administration and fluctuating blood levels characterized by saw-tooth kinetics, and hence improve the patient compliance (1). The success of CR devices is invariably hindered by their inability to localize in the selected region(s) of the gastrointestinal (GI) tract (2). Mucoadhesive drug delivery systems (DDS) offer a promising approach for controlled and site-specific delivery to the GI tract by attaching the devices to the mucus and mucosa of the tract via the process of bioadhesion. These mucoadhesive systems are also known to provide intimate contact between the dosage form and the absorptive mucosa, resulting in high drug flux through the absorbing tissue with improved bioavailability (3).

Hydralazine (HZ), a directly acting vasodilator, is widely prescribed in the treatment of hypertension and congestive heart failure. Albeit the drug is readily absorbed following oral administration, it is subjected to significant first-pass metabolism (4). Oral bio-

\footnotetext{
*Correspondence; e-mail: bsbhoop@yahoo.com, bsbhoop@pu.ac.in
} 
B. Singh et al.: Formulation development of oral controlled release tablets of hydralazine: Optimization of drug release and bioadhesive characteristics, Acta Pharm. 59 (2009) 1-13.

availability of the drug has been reported to range between 10 and $35 \%$, depending upon the extent of acetylation. HZ has a short biological half-life (2-4 h), low dose (50-100 mg) and high physicochemical stability. Owing to these favorable properties, several researchers have reported once-a-day CR formulation of HZ (5-8). No attempts, however, have been reported to date on formulation optimization of its CR bioadhesive system.

The objective of the current study was to develop mucoadhesive CR tablet formulations of HZ hydrochloride and optimize their bioadhesive and drug release characteristics employing the benefits of the 'Design of Experiments' (DoE) methodology (9).

\section{EXPERIMENTAL}

\section{Chemicals and reagents}

HZ hydrochloride was provided ex gratis by M/s Sarabhai Chemicals Ltd., India. Methocel K4M (hydroxypropylmethyl cellulose, HPMC) and Carbopol 971P (CP) were obtained as gift samples from M/s Dow Chemical Company, USA and M/s B.F. Goodrich Ltd., USA, respectively. Dibasic calcium phosphate $(\mathrm{CaHPO}, \mathrm{DCP})$ and magnesium stearate (MS) were obtained from M/s Namco Laboratories, India and Loba Chemie Ltd., India, respectively. All other materials used in the current study were of analytical grade and were used as received.

\section{Formulation}

Different mucoadhesive tablet formulations of $\mathrm{HZ}$ hydrochloride were formulated using varying amounts of polymers (CP and $\mathrm{HPMC}$ ) and DCP as the inert diluent, along with a fixed quantity of MS as the glidant and lubricant. Table I lists the various compositions employed during the study. HZ hydrochloride and the polymers, viz., CP and HPMC, were screened through a \# 80 mesh sieve (size: $180 \mu \mathrm{m}$ ) and DCP and MS were screened through a \# 120 mesh sieve (size: $125 \mu \mathrm{m}$ ) prior to use. All materials were accurately weighed and mixed intimately in a polyethylene bag for 10 minutes. The blended mix was subsequently compressed into $400 \mathrm{mg}$ tablets using flat-faced and round punches (12.8 mm diameter) fitted in a single-punch manual compression machine (Cadmach, India).

Table I. Composition of hydralazine hydrochloride tablets

\begin{tabular}{lc}
\hline \multicolumn{1}{c}{ Ingredient } & Mass $(\mathrm{mg})$ \\
\hline Hydralazine hydrochloride & 50 \\
CP 971P & $50-150$ \\
HPMC K4M & $60-180$ \\
Magnesium stearate & 5 \\
Dibasic calcium phosphate & q.s. to 400 \\
\hline
\end{tabular}

q.s. quantum satis 
B. Singh et al.: Formulation development of oral controlled release tablets of hydralazine: Optimization of drug release and bioadhesive characteristics, Acta Pharm. 59 (2009) 1-13.

\section{Experimental design}

A central composite design (CCD) for two factors at three levels each (with $\alpha=1$ ) was selected to optimize the varied response variables. The two factors, viz. polymer $\mathrm{X}_{1}$ $(\mathrm{CP})$ and polymer $\mathrm{X}_{2}$ (HPMC) of each polymer blend, were varied as required by the experimental design and the factor levels were suitably coded (Table II). The amount of MS was kept constant at $1.25 \%(\mathrm{~m} / \mathrm{m})$, while DCP was taken in a sufficient quantity to maintain a constant tablet mass of $400 \mathrm{mg}$. Time taken to release $50 \%$ of the drug $\left(t_{50}\right)$, extent of release until 18 hours (ext 18$)$, diffusional release exponent $(n)$, and bioadhesive strength $(\rho)$ were taken as the response variables.

\section{Tablet assay and physical evaluation}

Ten tablets were powdered and a quantity equivalent to $20 \mathrm{mg}$ of $\mathrm{HZ}$ hydrochloride was extracted with $60 \mathrm{~mL}$ of methanol. The resultant suspension was heated at $60{ }^{\circ} \mathrm{C}$ and shaken for 15 minutes. The contents were cooled and diluted up to $100 \mathrm{~mL}$ with methanol and filtered. Absorbance of the filtrate was measured at $\lambda_{\max }$ of $265 \mathrm{~nm}$ using a double beam UV/Vis spectrophotometer (140 A, Shimadzu, Japan) and the drug content was determined using the standard calibration equation taking the molar absorption coefficient $(\varepsilon)$ as $1.0107 \times 10^{4} \mathrm{~L} \mathrm{~mol}^{-1} \mathrm{~cm}^{-1}$. Tablets were also evaluated for hardness $(n=6)$ using a Monsanto type hardness tester (Campbell, India), friability $(n=6)$ using a Roche Friabilator (Tropical Lab Equipments, India), mass variation $(n=10)$ using an electronic balance (Mettler, Switzerland), and thickness $(n=10)$ using Vernier Callipers (Baker Gauges Ltd., India).

Table II. Factor combinations as per the chosen experimental design

\begin{tabular}{ccrr}
\hline & & \multicolumn{2}{c}{ Coded factor levels } \\
Formulation code & Trial No. & $\mathrm{X}_{1}$ & $\mathrm{X}_{2}$ \\
\cline { 3 - 4 } F1 & 1 & -1 & -1 \\
F2 & 2 & -1 & 0 \\
F3 & 3 & -1 & 1 \\
F4 & 4 & 0 & -1 \\
F5 & 5 & 0 & 0 \\
F6 & 6 & 0 & 1 \\
F7 & 7 & 1 & -1 \\
F8 & 8 & 1 & 0 \\
F9 & 9 & 1 & 1 \\
\hline & Translation of coded levels in actual units & 1 \\
$\mathrm{X}_{1}$ : CP (mg) & -1 & 0 & 150 \\
$\mathrm{X}_{2}$ : HPMC (mg) & 50 & 100 & 180 \\
\hline
\end{tabular}


B. Singh et al.: Formulation development of oral controlled release tablets of hydralazine: Optimization of drug release and bioadhesive characteristics, Acta Pharm. 59 (2009) 1-13.

\section{In vitro drug release studies}

Dissolution studies were carried out on all the formulation combinations in triplicate, employing the USP 27 (10) paddle method (Apparatus 2, Pharma Test, USA) at 50 rpm and $37 \pm 0.5^{\circ} \mathrm{C}$ using phosphate buffer $(\mathrm{PB}) \mathrm{pH} 6.6$ as the dissolution medium. An aliquot of sample was withdrawn periodically at suitable time intervals and the volume was replaced with an equivalent volume of plain dissolution medium. Samples were analyzed spectrophotometrically at $260 \mathrm{~nm}$. Drug release data obtained from in vitro dissolution were analyzed using the ZOREL software (11) with in-built provisions for applying the correction factor for volume and drug losses during sampling (12). Drug release data were fitted into the Korsemeyer-Peppas model (13):

$$
\frac{M_{t}}{M_{\infty}}=k_{1} t^{n}+k_{2} t^{2 n}
$$

where $M_{t}$ is the amount of drug released at time $t, M_{\infty}$ is the amount of drug released at an infinite time, $k_{1}$ and $k_{2}$ are the magnitudinal contributions of diffusion and polymer relaxation mechanism, and $n$ is the Fickian diffusion coefficient.

Based on the phenomenological analysis, the type of release, i.e., whether Fickian, non-Fickian (anomalous) or zero-order, was predicted. The value of $t_{50}$ was calculated using the Stineman interpolation option of the GRAPH software (Version 2, Micromath Inc., USA). Dissolution studies employing graded concentrations of DCP and without DCP were carried out earlier to ratify its inertness on drug release kinetics.

\section{Ex vivo bioadhesion studies}

Bioadhesion studies were conducted employing a slightly modified version of an in-house fabricated bioadhesion assembly $(3,14)$. Porcine gastric mucosa was used as the model membrane. The mucosa was kept frozen in $\mathrm{PB} \mathrm{pH} 7.4$ and thawed to room temperature before use. The mucosal membrane was excised by removing the underlying connective and adipose tissue and was equilibrated at $37 \pm 1{ }^{\circ} \mathrm{C}$ for $30 \mathrm{~min}$ in buffer (PB pH 6.6) before the bioadhesion evaluation study. The tablet $(n=3)$ was lowered onto the mucosa under a constant weight of $49 \mathrm{~N}$ for a total contact period of $1 \mathrm{~min}$. Bioadhesive strength was assessed in terms of weight, in $\mathrm{N}$, required to detach the tablet from the membrane.

Bioadhesive strength of the optimized formulation was also investigated as a function of $\mathrm{pH}$ using eight buffers $\left(0.1 \mathrm{~mol} \mathrm{~L}^{-1}\right)$ with $\mathrm{pH}$ ranging between 1.2 and 8.0.

\section{Optimization data analysis}

For the studied design, the multiple linear regression analysis (MLRA) method was applied using the Design Expert software version 6.0.10 (Stat-Ease, USA) to fit the full second-order polynomial equation with added interaction terms. Polynomial regression results were demonstrated for the studied responses. Finally, the prognosis of optimum formulation was conducted in two stages; first, a feasible space was located and second, an exhaustive grid search was conducted to predict the possible solutions. 
B. Singh et al.: Formulation development of oral controlled release tablets of hydralazine: Optimization of drug release and bioadhesive characteristics, Acta Pharm. 59 (2009) 1-13.

\section{DoE validation and selection of optimum formulation}

Eight formulations were selected as check-points to validate DoE optimization. Mucoadhesive tablet formulations were compressed using the chosen optimal composition and evaluated for physical tests, tablet assay, dissolution performance and bioadhesion, as described earlier. The observed and predicted responses were critically compared. Linear correlation plots were constructed for the eight chosen optimized formulations. Residual graphs between predicted and observed responses were also constructed separately and the percent bias (error) was calculated with respect to the observed responses. Amongst the formulations selected for validation $(n=8)$ and prepared as per the experimental design $(n=9)$ one was carefully chosen as the optimum formulation by »trading off « the values of response parameters. Values of $t_{50}$, ext $18, \rho$ and $n$ were maximized within the available domain.

\section{RESULTS AND DISCUSSION}

\section{Selection of polymers and suitable experimental design}

The polymers, viz. CP and HPMC, were selected owing to their excellent bioadhesive strength, release rate controlling ability (15), non-toxicity, non-irritancy, stability at GI $\mathrm{pH}$ and compatibility with the drug. Successful use of the polymer combination of an ionic polymer (like $\mathrm{CP}$ ) and a nonionic polymer (like HPMC) is known to provide the formulation with controlled drug release along with desired mucoadhesive properties $(14,16)$.

A CCD for two factors at three levels with $\alpha=1$, equivalent to $3^{2}$ factorial design (FD), was chosen as the experimental design. This is an effective second-order experimental design associated with a minimum of experiments to estimate the influence of individual variables (main effects) and their second-order effects $(14,1718)$. Further, this design has an added advantage of determining the quadratic response surface, not estimable using an FD at two levels (19).

\section{Drug content and physical evaluation}

The content of drug in formulations varied between 98.5 and $100.2 \%(\mathrm{~m} / \mathrm{m})$ (mean $\pm \mathrm{SD}=99.3 \pm 0.7 \%)$. Tablet mass varied between 399.09 and $403.06 \mathrm{mg}(401.08 \pm 1.62 \mathrm{mg})$, thickness between 2.51 and $2.91 \mathrm{~mm}(2.71 \pm 0.17 \mathrm{~mm})$, hardness between 4.67 and $7.04 \mathrm{~kg} \mathrm{~cm}^{-2}\left(5.86 \pm 1.16 \mathrm{~kg} \mathrm{~cm}^{-2}\right)$, and friability ranged between 0.51 and $0.76 \%(\mathrm{~m} / \mathrm{m})$ $(0.64 \pm 0.12 \%)$. Thus, all physical parameters of the compressed matrices were within the permissible limits of USP (10).

\section{In vitro drug release studies}

Addition of either water-soluble or insoluble diluents in large quantities can markedly increase the release rate of hydrosoluble active principles (20). Preliminary studies carried out at graded DCP levels, viz., 1:1, 1:3 and 1:5, and without DCP indicated near 
superimposability in the dissolution curves with values of the similarity factor $\left(\mathrm{f}_{2}\right)$ ranging between 89.9 to 97.8 (21). This analogy of dissolution profiles ratifies the inertness of DCP in the present drug release studies.

As evident from the diverse nature of dissolution profiles (Fig. 1), the influence of polymer levels seems to be vital in regulating the drug release. Drug release rate curves (Fig. 1, inset) of all the formulations portray an initial burst release of the drug, characteristic of most hydrophilic matrices $(3,14,22)$. Summary of the drug release parameters (Table III) shows that the value of $n$ varies from 0.4653 to 0.6618 , distinctly delineating the non-Fickian release behaviour of all formulations. Values of the kinetic constant, $k$, showed a declining trend with an increase in the level of each polymer, construing an appreciable change in the polymer matrix with a change in the polymer composition. Relatively high magnitudes of the Fickian diffusion constant, $k_{1}$, vis-à-vis the polymer relaxation constant, $k_{2}$, clearly show that the drug release was predominantly determined by Fickian diffusion, with negligible contribution of polymer relaxation. This is in consonance with several research findings that a mixture of HPMC with $\mathrm{CP}$ results in the reduction of polymer viscosity owing to reduced hydration of the matrix and facilitating drug diffusion through the polymer hydrogel $(14,16,23,24)$. Table III reveals that the overall rate of drug release tended to decrease with an increase in concentration of HPMC or CP. The values of $t_{50}$ were found to rise markedly from 3.49 to $18.11 \mathrm{~h}$ from the lowest to the highest level of both polymers, respectively. In contrast, the values of $\operatorname{ext}_{18}$ decreased significantly with an increase in the content of either polymer. Nearly $50 \%$ of the drug remained captive in the hydrophilic matrix up to 18 hours at the highest levels of both polymers, which may lead to appreciable diminution in the extent of drug absorption. Moderate levels of polymers should, therefore, be employed to yield an apt value of $t_{50}$ and $\operatorname{ext}_{18}$.

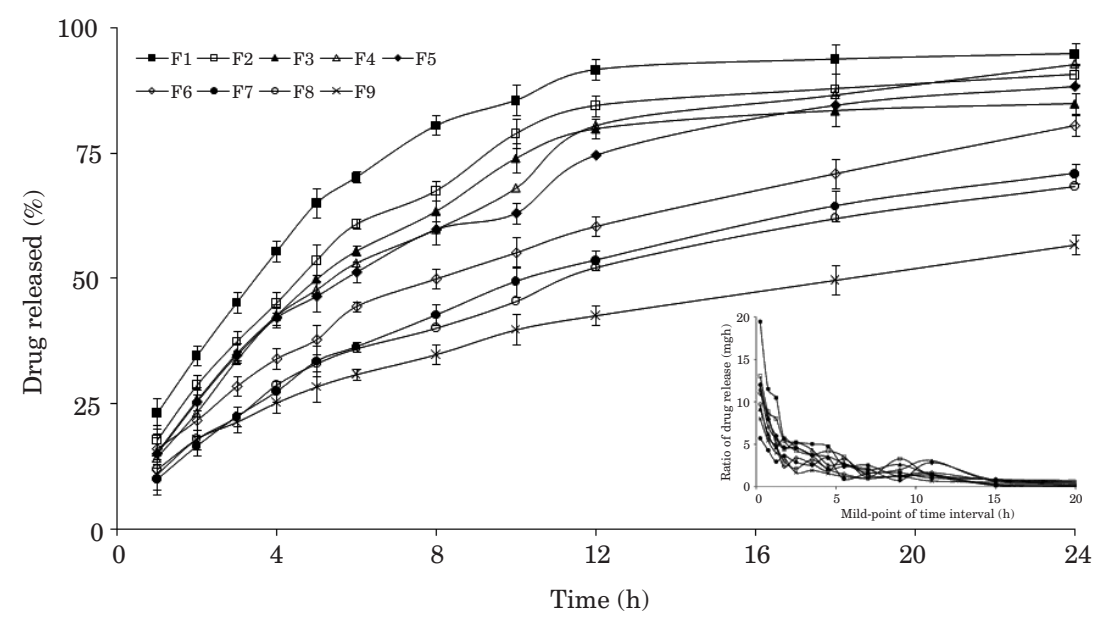

Fig. 1. Dissolution profiles of various mucoadhesive tablet formulations (F1 to F9) of hydralazine hydrochloride prepared as per the experimental design $(n=3)$. The crossbars indicate \pm 1 SD. The inset shows the corresponding drug release rate profiles. 
B. Singh et al.: Formulation development of oral controlled release tablets of hydralazine: Optimization of drug release and bioadhesive characteristics, Acta Pharm. 59 (2009) 1-13.

Table III. Drug release parameters of various mucoadhesive formulations prepared as per the experimental design ${ }^{a}$

\begin{tabular}{|c|c|c|c|c|c|c|c|c|c|}
\hline \multirow{2}{*}{$\begin{array}{l}\text { For- } \\
\text { mula- } \\
\text { tion } \\
\text { code }\end{array}$} & \multicolumn{2}{|c|}{$\begin{array}{l}\text { Formulation } \\
\text { composition }\end{array}$} & \multirow{2}{*}{$\begin{array}{l}\text { Release } \\
\text { exponent } \\
(n)\end{array}$} & \multirow{2}{*}{$\begin{array}{c}\text { Kinetic } \\
\text { constant } \\
(k)\end{array}$} & \multirow{2}{*}{$\begin{array}{l}\text { Fickian } \\
\text { diffusion } \\
\text { constant } \\
\left(k_{1}\right)\end{array}$} & \multirow{2}{*}{$\begin{array}{l}\text { Polymer } \\
\text { relaxation } \\
\text { constant } \\
\left(k_{2}\right)\end{array}$} & \multirow{2}{*}{$\begin{array}{l}\text { Extent of } \\
\text { drug re- } \\
\text { lease till } \\
18 \text { hours } \\
\left(\operatorname{ext}_{18}, \%\right)\end{array}$} & \multirow{2}{*}{$t_{50}(\mathrm{~h})$} & \multirow{2}{*}{$\begin{array}{l}\text { Rate of } \\
\text { drug } \\
\text { release } \\
\left(\mathrm{mg} \mathrm{h}^{-1}\right)\end{array}$} \\
\hline & $\begin{array}{l}\mathrm{CP} \\
(\mathrm{mg})\end{array}$ & $\begin{array}{l}\text { HPMC } \\
(\mathrm{mg})\end{array}$ & & & & & & & \\
\hline F1 & 50 & 60 & 0.4653 & 0.271 & 1.334 & -0.0052 & 93.71 & 3.49 & $3.68 \pm 3.31$ \\
\hline $\mathrm{F} 2$ & 50 & 120 & 0.5331 & 0.208 & 1.240 & 0.0088 & 87.73 & 4.64 & $3.31 \pm$ \\
\hline F3 & 50 & 180 & 0.6092 & 0.165 & 1.172 & 0.0226 & 83.45 & 5.01 & $3.62 \pm 2.52$ \\
\hline $\mathrm{F} 4$ & 100 & 60 & 0.6017 & 0.166 & 1.1 & 0.0206 & 88.25 & 5.47 & $3.11 \pm 2.03$ \\
\hline F5 & 100 & 120 & 0.5433 & 0.182 & 1.202 & & 84.51 & 5.81 & $2.94 \pm 2.22$ \\
\hline F6 & 100 & 180 & 0.5131 & 0.165 & 1.777 & & 70.87 & 8.03 & $2.52 \pm 2.16$ \\
\hline F7 & 150 & 60 & 0.6618 & 0.103 & 1.093 & 0.0239 & 64.40 & 10.24 & $2.48 \pm 1.55$ \\
\hline F8 & 150 & 120 & 0.5607 & 0.125 & 1.129 & 0.0118 & 61.99 & 11.33 & $2.13 \pm 1.53$ \\
\hline F9 & 150 & 180 & 0.5041 & 0.121 & 1.130 & 0.0037 & 49.71 & 18.11 & $1.72 \pm 1.47$ \\
\hline
\end{tabular}

a Mean $\pm \mathrm{SD} ; n=3$

\section{Ex vivo bioadhesive strength determination}

Fig. 2 construes an increasing trend in the bioadhesive strength with an increased amount of either polymer, in agreement with the literature $(3,14,25)$. Hydrogels are known to swell readily on contact with the hydrated mucous membrane (14). This glass-rubbery transition provides hydrogel plasticization, resulting in a large adhesive surface for maximum contact with mucin and flexibility to the polymer chains for interpenetration with mucin. Increasing the polymer amount may provide more adhesive sites and polymer chains for interpenetration with mucin, resulting in augmentation of bioadhesive strength. Although the maximum value of bioadhesive strength is attained at the highest levels of both polymers, the effect of $\mathrm{CP}$ was found to be distinctly more pronounced than that of HPMC.

Fig. 2. Bar diagram showing bioadhesive strength determined as the force of detachment of mucoadhesive tablet formulations (F1 to F9) of hydralazine hydrochloride prepared as per central composite design ( $n$ $=3)$. The crossbars indicate +1 SD.

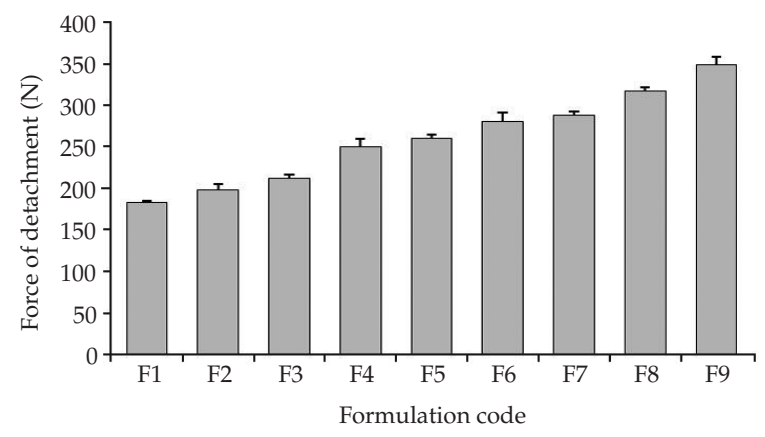


The bioadhesive strength tends to rise uptill $\mathrm{pH} 5$ and reaches almost plateau levels thereafter. The results are in agreement with earlier reports that optimum gel strengthening of mucoadhesive polymers occurs in weakly acidic environments, where both the polymer and the mucus have their optimum spatial conformation and thereby, improved viscoelasticity (26). Thus, it can be concluded that the optimized formulation has a distinct bioadhesive potential throughout the $\mathrm{pH}$ environment of the GI tract. Such optimized mucoadhesive tablets offer an economical and simpler technology as a once-a-day GI retentive CR formulation system of the drug.

\section{Exploration of polymer mechanism using RSM}

Quite high values of $R^{2}$ of the MLRA coefficients for all four responses, ranging between 0.9946 and 0.9999 , vouch high prognostic ability of the RSM polynomials:

$$
Y=\beta_{o}+\beta_{1} X_{1}+\beta_{2} X_{2}+\beta_{3} X_{1} X_{2}+\beta_{4} X_{1}^{2}+\beta_{5} X_{2}^{2}+\beta_{6} X_{1} X_{2}^{2}+\beta_{7} X_{2} X_{1}^{2}
$$

Seven coefficients $\left(\beta_{1}\right.$ to $\left.\beta_{7}\right)$ were calculated representing $\beta_{0}$ as the intercept, and $\beta_{3}$ to $\beta_{7}$ various quadratic and interaction terms.

Figs. $3 a$ to 6 a portray the 3-dimensional response surface plots for the studied response properties, viz., $t_{50}, \operatorname{ext}_{18}, \rho$ and $n$ while Figs. $3 \mathrm{~b}$ to $6 \mathrm{~b}$ depict the corresponding contour plots. Fig. 3a shows a nonlinear trend in the values of $t_{50}$, markedly increasing with the augmentation of CP levels. With HPMC, the values of $t_{50}$ tend to rise nonlinearly, followed by an asymptote at the low levels of CP. The same is evident from the corresponding contour plot (Fig. 3b), showing somewhat declining nonlinear contour lines. Figs. $4 \mathrm{a}$ and $4 \mathrm{~b}$ reveal a sharp decline in the value of $\operatorname{ext}_{18}$ with an increase in the amount of each of the polymers, i.e., $\mathrm{CP}$ and HPMC, the influence of $\mathrm{CP}$ being much more pronounced. Nonlinear descending contour lines in Fig. $4 \mathrm{~b}$ further show that the variation in $\operatorname{ext}_{18}$ is a complex function of the polymer levels, the effect of HPMC being less prominent. Fig. 5a shows a nearly linear ascending pattern for the values of bioadhesive strength, as the content of either polymer is increased, the effect being much more prominent with $\mathrm{CP}$ than with HPMC. Maximum bioadhesive strength is observable at the highest levels

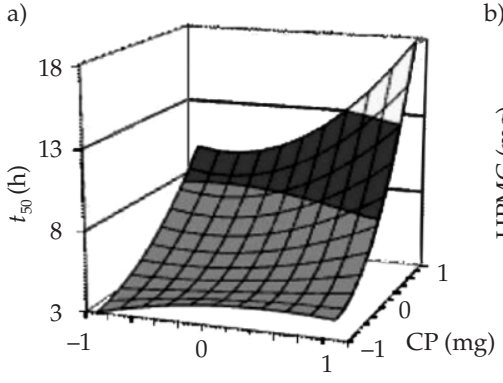

$\operatorname{HPMC}(\mathrm{mg})$

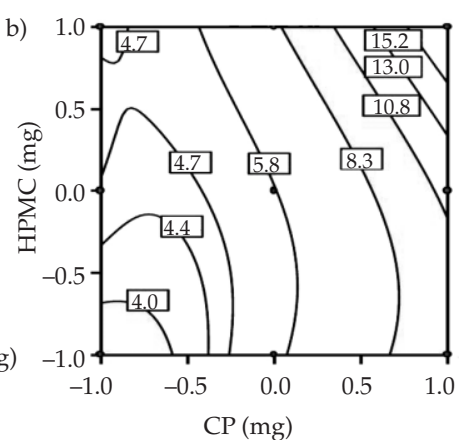

Fig. 3. a) Response surface plot showing the influence of $C P$ and HPMC on the value of $t_{50}$ of mucoadhesive tablet formulations of hydralazine hydrochloride; b) the corresponding contour plot. 
B. Singh et al.: Formulation development of oral controlled release tablets of hydralazine: Optimization of drug release and bioadhesive characteristics, Acta Pharm. 59 (2009) 1-13.

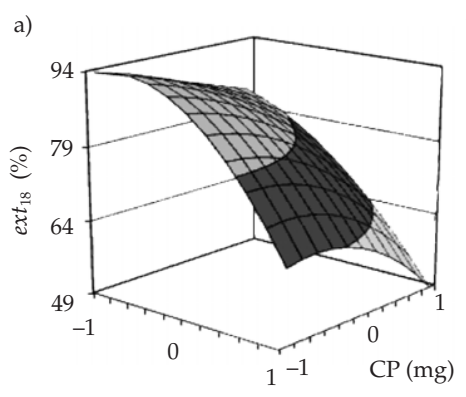

$\operatorname{HPMC}(\mathrm{mg})$

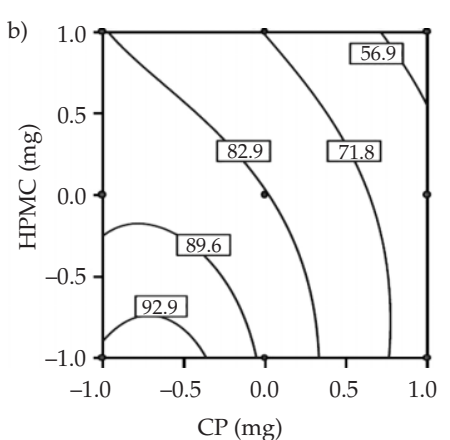

Fig. 4. a) Response surface plot showing the influence of CP and HPMC on the value of the extent of drug release up to $18 \mathrm{~h}\left(\operatorname{ext}_{18}\right)$ of mucoadhesive tablet formulations of hydralazine hydrochloride; b) the corresponding contour plot.
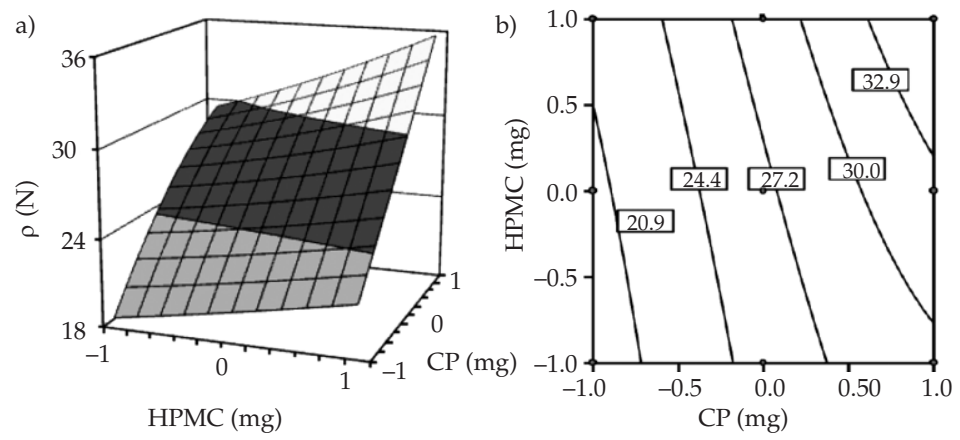

Fig. 5. a) Response surface plot showing the influence of $C P$ and HPMC on the value of bioadhesive strength $(\rho)$ of mucoadhesive tablet formulations of hydralazine hydrochloride; b) the corresponding contour plot.
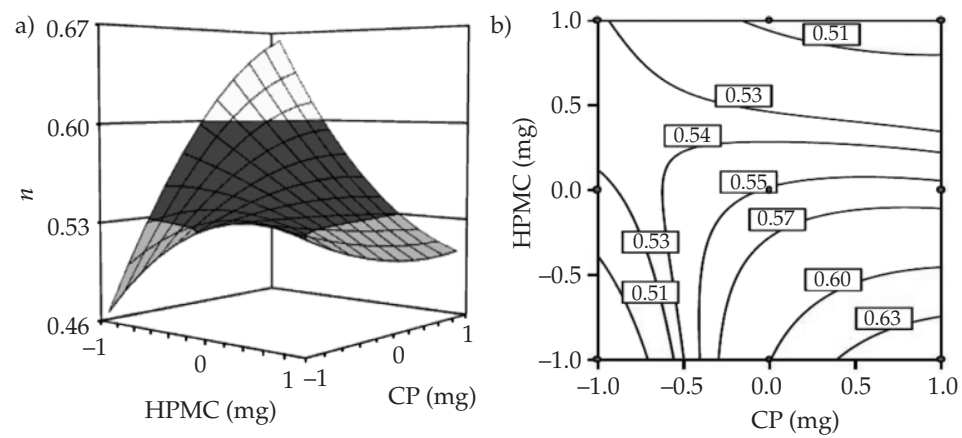

Fig. 6. a) Response surface plot showing the influence of CP and HPMC on the value of the release exponent $(n)$ of mucoadhesive tablet formulations of hydralazine hydrochloride; $\mathbf{b}$ ) the corresponding contour plot. 
B. Singh et al.: Formulation development of oral controlled release tablets of hydralazine: Optimization of drug release and bioadhesive characteristics, Acta Pharm. 59 (2009) 1-13.

of both polymers, viz., CP and HPMC. Nearly vertical contour lines (Fig. 5b) corroborate the markedly significant influence of CP on $\rho$ values vis-a-vis HPMC. Fig. 6a portrays a twisted nonlinear relationship of $n$ with increasing amounts of HPMC and CP. At low

Table IV. Comparison of the experimental results with the predicted responses

\begin{tabular}{|c|c|c|c|c|}
\hline $\begin{array}{l}\text { Formulation composition } \\
\qquad \mathrm{CP} / \mathrm{HPMC}(\mathrm{mg})\end{array}$ & $\begin{array}{c}\text { Response } \\
\text { variable }\end{array}$ & $\begin{array}{l}\text { Experimental } \\
\text { value }\end{array}$ & $\begin{array}{l}\text { Predicted } \\
\text { value }\end{array}$ & $\begin{array}{c}\text { Percentage } \\
\text { bias }(\%)\end{array}$ \\
\hline \multirow{4}{*}{$50 / 68.4$} & $t_{50}(\mathrm{~h})$ & 5.29 & 5.07 & 4.2 \\
\hline & $\operatorname{ext}_{18}(\%)$ & 91.51 & 90.75 & 0.8 \\
\hline & $\rho(\mathrm{N})$ & 254.89 & 252.94 & 0.8 \\
\hline & $n$ & 0.6302 & 0.6054 & 3.9 \\
\hline \multirow{4}{*}{$94 / 64.8$} & $t_{50}(\mathrm{~h})$ & 5.07 & 5.18 & -2.2 \\
\hline & $\operatorname{ext}_{18}(\%)$ & 91.13 & 89.60 & 1.7 \\
\hline & $\rho(\mathrm{N})$ & 258.13 & 258.43 & -0.1 \\
\hline & $n$ & 0.6071 & 0.6052 & 0.3 \\
\hline \multirow{4}{*}{$86 / 64.8$} & $t_{50}(\mathrm{~h})$ & 5.03 & 5.12 & -1.8 \\
\hline & $\operatorname{ext}_{18}(\%)$ & 87.12 & 88.94 & -2.1 \\
\hline & $\rho(\mathrm{N})$ & 258.72 & 260.48 & -0.7 \\
\hline & $n$ & 0.6053 & 0.5955 & 1.2 \\
\hline \multirow{4}{*}{$60 / 67.2$} & $t_{50}(\mathrm{~h})$ & 5.25 & 5.17 & 1.5 \\
\hline & $\operatorname{ext}_{18}(\%)$ & 88.10 & 87.63 & 0.5 \\
\hline & $\rho(\mathrm{N})$ & 251.06 & 252.05 & -0.4 \\
\hline & $n$ & 0.5789 & 0.5588 & 3.5 \\
\hline \multirow{4}{*}{$102 / 74.4$} & $t_{50}(\mathrm{~h})$ & 5.10 & 5.09 & 0.2 \\
\hline & $\operatorname{ext}_{18}(\%)$ & 87.71 & 87.13 & 0.7 \\
\hline & $\rho(\mathrm{N})$ & 246.17 & 248.63 & -1.0 \\
\hline & $n$ & 0.5619 & 0.5482 & 0.6 \\
\hline \multirow{4}{*}{$110 / 180$} & $t_{50}(\mathrm{~h})$ & 12.36 & 12.27 & 0.7 \\
\hline & $\operatorname{ext}_{18}(\%)$ & 61.31 & 60.93 & 0.6 \\
\hline & $\rho(\mathrm{N})$ & 320.56 & 322.03 & -0.5 \\
\hline & $n$ & 0.5571 & 0.5421 & 2.7 \\
\hline \multirow{4}{*}{$130 / 144$} & $t_{50}(\mathrm{~h})$ & 9.17 & 9.32 & -1.6 \\
\hline & $\operatorname{ext}_{18}(\%)$ & 70.49 & 70.09 & 0.6 \\
\hline & $\rho(\mathrm{N})$ & 298.99 & 297.62 & 0.5 \\
\hline & $n$ & 0.5393 & 0.5232 & 3.0 \\
\hline \multirow{4}{*}{$140 / 168$} & $t_{50}(\mathrm{~h})$ & 15.08 & 15.56 & -3.2 \\
\hline & $\operatorname{ext}_{18}(\%)$ & 54.52 & 54.65 & -0.2 \\
\hline & $\rho(\mathrm{N})$ & 337.02 & 335.35 & 0.5 \\
\hline & $n$ & 0.5128 & 0.5049 & 1.5 \\
\hline \multicolumn{2}{|c|}{ Mean $( \pm$ SD) percent } & & $0.3 \pm 1.8$ & \\
\hline
\end{tabular}


B. Singh et al.: Formulation development of oral controlled release tablets of hydralazine: Optimization of drug release and bioadhesive characteristics, Acta Pharm. 59 (2009) 1-13.

HPMC levels, the value of $n$ increases nonlinearly with an increase in CP. On the other hand, the value of $n$ at low levels of CP increases to an asymptote with an increasing amount of HPMC. Thus, the current results seem to be in agreement with the findings of Nokhodchi et al. (24), indicating an ambiguous relationship of $n$ with the change in polymer composition. The corresponding contour plot (Fig. 6b) also shows an unambiguous nonlinear trend with a "saddle point « at the low levels of CP and high levels of HPMC (9).

\section{DoE validation and selection of optimum formulation}

Upon comparison of the observed responses with those of the anticipated ones (Table IV), the prediction error varied between -3.2 and $4.2 \%$ (mean $\pm \mathrm{SD}=0.32 \pm 1.8 \%$ ). Linear correlation plots drawn between the predicted and observed responses after forcing the line through the origin, also demonstrated high values of $R$ (0.9771 to 0.9989), indicating excellent goodness of fit $(p<0.001)$. The corresponding residual plots show nearly uniform and random scatter around the mean values of response variables.

The optimum formulation was selected by »trading off « various response variables and adopting the following maximizing criteria: $t_{50}>4.5 \mathrm{~h} ; \operatorname{ext}_{18}>80 ; 0.57<n<0.89$; $\rho>235.2 \mathrm{~N}$. Upon comprehensive evaluation of grid searches, the formulation (CP: $50.0 \mathrm{mg}$ and HPMC: $68.4 \mathrm{mg}$ ) fulfilled the optimal criteria of best regulation of the release rate and bioadhesive strength with $t_{50}$ of $5.29 \mathrm{~h}$, ext $t_{18}$ of $91.51 \%, n$ of 0.6302 and $\rho$ of $254.9 \mathrm{~N}$.

\section{CONCLUSIONS}

The current studies are aimed at successful development and optimization of a once-a-day formulation of $\mathrm{HZ}$ hydrochloride with high regulation of the release rate and bioadhesive strength. Suitable balancing between the levels of two polymers (CP and HPMC) is imperative to acquire maximum extension in drug release and adequate bioadhesion. The bioadhesive nature of formulation may prolong the GI retention in an actual in vivo situation and eventually augment the extent of release and absorption. Miniscule bias between the observed and predictive responses confirms the high prognostic ability of the study design. The study offers a platform technology, the results of which can be successfully extrapolated to the soluble salts of other basic drugs as well.

\section{REFERENCES}

1. Y. W. Chien, Rate-control drug delivery systems: Controlled release vs. sustained release, Med. Prog. Technol. 15 (1989) 21-46.

2. Y. Song, Y. Wang, R. Thakur, V. M. Meidan and B. Michniak, Mucosal drug delivery: membranes, methodologies, and applications, Crit. Rev. Ther. Drug Carrier Syst. 21 (2004) 195-256; DOI: 10.1615/CritRevTherDrugCarrierSyst.v21.i3.20.

3. B. Singh, S. K. Chakkal and N. Ahuja, Formulation and optimization of controlled release mucoadhesive tablets of atenolol using response surface methodology, AAPS PharmSciTech 7 (2006) E1-E10; DOI: 10.1208/pt070103. 
B. Singh et al.: Formulation development of oral controlled release tablets of hydralazine: Optimization of drug release and bioadhesive characteristics, Acta Pharm. 59 (2009) 1-13.

4. J. A. Oates and N. J. Brown, Antihypertensive Agents and the Drug Therapy of Hypertension, in Goodman \& Gilman's The Pharmacological Basis of Therapeutics, $10^{\text {th }}$ ed. (Ed. J. G. Hardman and L. E. Limbird), Mc Graw Hill Medical Publishing Division, New York 2001, pp. 871-900.

5. K. Wulff, K. Lenz, A. R. Krogsgaard and B. Holst, Hydralazine in arterial hypertension. Randomized, double-blind comparison between conventional and slow-release preparations, Ugeskr. Laeger. 142 (1980) 1862-1865.

6. T. Talseth, P. Fauchald and J. F. Pape, Hydralazine slow-release: Observations on serum profile and clinical efficacy in man, Curr. Ther. Res. Clin. Exp. 21 (1977) 157-168.

7. J. Adir, S. M. Janda, C. L. Curry, R. E. Taylor, C. D. Poku and K. S. Rotenberg, Comparative efficacy and safety of immediate-release and controlled-release hydralazine in black hypertensive patients, Clin. Ther. 9 (1987) 640-650.

8. J. H. Silas, L. E. Ramsay and S. Freestone, Hydralazine once daily in hypertension, Br. Med. J. 284 (1982) 1602-1624.

9. B. Singh, R. Kumar and N. Ahuja, Optimizing drug delivery systems using systematic »design of experiments«. Part I: fundamental aspects, Crit. Rev. Ther. Drug Carrier Syst. 22 (2005) 27-105; DOI: 10.1615/CritRevTherDrugCarrierSyst.v22.i1.20.

10. United States Pharmacopoeia 27, National Formulary 22, USP Convention, Rockville 2004.

11. B. Singh and S. Singh, A compreshensive computer program for study of drug release kinetics from compressed matrices, Indian J. Pharm. Sci. 60 (1998) 313-316.

12. B. Singh, T. Kaur and S. Singh, Correction of raw dissolution data for loss of drug during sampling, Indian J. Pharm. Sci. 59 (1997) 196-199.

13. R. W. Korsemeyer, R. Gurny, E. Doelker, P. Buri and N. Peppas, Mechanisms of solute release from porous hydrophilic polymers, Int. J. Pharm. 15 (1983) 23-35.

14. B. Singh and N. Ahuja, Development of controlled-release buccoadhesive hydrophilic matrices of diltiazem hydrochloride: optimization of bioadhesion, dissolution, and diffusion parameters, Drug Dev. Ind. Pharm. 28 (2002) 431-442; DOI: 10.1081/DDC-120003004.

15. V. V. Yamsani, R. Gannu, C. Kolli, M. E. Rao and M. R. Yamsani, Development and in vitro evaluation of buccoadhesive carvedilol tablets, Acta Pharm. 57 (2007) 185-197; DOI: 10.2478/v10007-007-0015-7.

16. A. O. Nur and J. S. Zhang, Captopril floating and/or bioadhesive tablets: design and release kinetics, Drug Dev. Ind. Pharm. 26 (2000) 965-969; DOI: 10.1081/DDC-100101323.

17. B. Singh, M. Dahiya, V. Saharan and N. Ahuja, Optimizing drug delivery systems using systematic »design of experiments«. Part II: retrospect and prospects, Crit. Rev. Ther. Drug Carrier Syst. 22 (2005) 215-294; DOI: 10.1615/CritRevTherDrugCarrierSyst.v22.i3.10.

18. J. B. Schwartz and R. E. Connor, Optimization Techniques in Pharmaceutical Formulation and Processing, in Modern Pharmaceutics (Eds. G. S. Banker and C. T. Rhodes), Marcel Dekker, New York 1996, pp. 727-752.

19. B. Singh, R. K. Gupta and N. Ahuja, Computer-assisted optimization of pharmaceutical formulations and processes, in Pharmaceutical Product Development (Ed. N. K. Jain), CBS Publishers, New Delhi 2006, pp. 273-318.

20. M. J. Vazquaz, B. Perez Macros, J. L. Gomez-Amoza and N. A. Peppas, Influence of technological variables on release of drugs from hydrophilic matrices, Drug Dev. Ind. Pharm. 18 (1992) 1355-1375.

21. USFDA Guidance for Industry: Dissolution Testing of Immediate Release Solid Oral Dosage Forms, U.S. Department of Health and Human Services, Food and Drug Administration: Center for Drug Evaluation and Research (CDER) (1997), Rockwille 1997.

22. S. Chopra, G. V. Patil and S. K. Motwani, Release modulating hydrophilic matrix systems of losartan potassium: Optimization of formulation using statistical experimental design, Eur. J. Pharm. Biopharm. 66 (2007) 73-82; DOI: 10.1016/j.ejpb.2006.09.001. 
B. Singh et al.: Formulation development of oral controlled release tablets of hydralazine: Optimization of drug release and bioadhesive characteristics, Acta Pharm. 59 (2009) 1-13.

23. B. Perez-Marcos, J. L. Ford, D. J. Armstrong, P. N. Elliott, C. Rostron and J. E. Hogan, Influence of $\mathrm{pH}$ on the release of propranolol hydrochloride from matrices containing hydroxypropylmethylcellulose K4M and carbopol 974, J. Pharm. Sci. 85 (1996) 330-334; DOI: 10.1021/js950359z.

24. A. Nokhodchi, J. L. Ford and M. H. Rubinstein, Studies on the interaction between water and (hydroxypropyl)methylcellulose, J. Pharm. Sci. 86 (1997) 608-615; DOI: 10.1021/js960279a.

25. G. Ponchel, F. Touchard, D. Duchene and N. A. Peppas, Bioadhesive analysis of controlled release systems. I. Fracture and interpenetration analysis in poly(acrylic acid) containing systems, J. Control. Rel. 5 (1987) 129-141; DOI: 10.1016/0168-3659(87)90004-6.

26. F. Madson, K. Eberth and J. D. Smart, A rheological assessment of the nature of interactions between mucoadhesive polymers and a homogenised mucus gel, Biomaterials 19 (1998) 1083-1092.

\section{$S A \check{Z} E T A K$}

\section{Razvoj tableta hidralazina s kontroliranim oslobađanjem za oralnu uporabu: Optimizacija oslobađanja ljekovite tvari i bioadhezivnih svojstava}

BHUPINDER SINGH, SONIA PAHUJA, RISHI KAPIL i NAVEEN AHUJA

Istraživanje uključuje razvoj bioadhezivnih hidrofilnih matriksa hidralazin hidroklorida za oralnu uporabu, optimizaciju oslobađanja ljekovite tvari in vitro i bioadhezivnih svojstava ex vivo na sluznici želuca svinje. $3^{2}$ dizajniranje korišteno je za sistematsko optimiranje formulacija koje u sastavu imaju dva polimera, karbomer i hidroksipropilmetilcelulozu. Nacrtane su krivulje ovisnosti i grubo odabrane optimalne formulacije. Validacija optimiranih formulacija ukazuje vrlo visoki stupanj predvidljivosti. Razvijena je optimirana formulacija hidralazina koja se dozira jednom dnevno, a ima izvrsnu bioadhezivnost i sposobnosti kontroliranog oslobađanja.

Ključne riječi: hidralazin, dizajniranje eksperimenta, bioadhesivnost, metoda površina, gastrointestinalni terapijski sustav, hidrofilni matriksi

University Institute of Pharmaceutical Sciences (UGC Centre for Advanced Studies)

Panjab University, Chandigarh-160014, India 